\title{
Hardwiring Serendip
}

\author{
Give chance its due
}

by John Koch

$\mathrm{T}$ here is a generation of us who, on our deathbeds, will not be obsessed with our lost loves and secret sins, but with trying to remember something we once read as a child in the Reader's Digest. If our parents didn't subscribe, our grandparents did, and there was usually a substantial pile to go through during family visits.

We never read the articles, which were usually written by parts of our bodies to explain how they could hurt us if we didn't treat them right. We just read the jokes and anecdotes for which people were paid unbelievable sums (maybe $\$ 25$ for a paragraph), if the humor editor liked them.

I remember one story that went something like this: Her husband's job had taken an American woman to an African country. Bored, she went to the local library and selected a book or two. When it came time to check out, she was told that patrons must check out nine books at a time. She protested, but the librarian grabbed books at random, piled them up until the stack was nine books high, and charged them out to her. She took all nine books home. If you know anything about the Reader's Digest humor editor, you know that she read and enjoyed them all.

We librarians strive to make our systems predictable. An author's divorce or remarriage or decision to change his or her name to an unpronounceable symbol can cause a flurry of activity in technical services offices around the country. We try to arrange it so that when someone types asparagus into an OPAC, he or she doesn't get a list of books on dancing the polka. We have devised authorized subject headings, such as "American Revolution Bicentennial Two Dollar Bill Postage-Stamp Cancellations" and "Contango and Backwardation" to prevent ambiguity.

\section{Ambiguity can be the answer}

But ambiguity is not totally preventable, and, in certain circumstances, we can use it. We try 
From now on, libraries should

refuse to accept delivery on a new

automation system unless the

OPAC interface includes a button

that says "RANDOMIZE," or maybe

"POTLUCK."

to think in straight lines, but are often most productive when we deal in analogy and metaphor. Creative leaps happen after we have steeped ourselves in a problem and given up on horizontal thinking. Our unconscious mind keeps on working and sometimes finds a solution in the patterns produced by something far removed from the original problem.

Maybe a horticulturist will be mulling over an asparagus disease, and a book on polkas will provide the insight she needs: "Let's lay out the beds ONE-two-three-four, ONE-twothree-four." Realms of discourse and thought interpenetrate, and ideas that arose in mathematics are applied to botany, physics, economics, medicine, and French literature; eventually, a particularly knotty problem in topology is called something like "Baudelaire's conundrum."

It is time we give chance its due. From now on, libraries should refuse to accept delivery on a new automation system unless the OPAC interface includes a button that says "RANDOMIZE," or maybe "POTLUCK." Click on this button and you get ten titles from the databaseany ten titles, chosen by a random number generator. You may look at these titles for divine guidance. Or just for fresh ideas.

Creative writing teachers may assign students to write papers that cite any seven of Morpbology of Vascular Plants, Lower Groups (Psilopbytales to Filicales); National Party Platforms, 1840-1972; Great Riding Schools of the World; Metbods of Interpreting Plato and bis Dialogues; Nutrition and Diet Therapy; Field Guide to the Butterflies of Africa; Emily Dickinson: an Interpretive Biography; Lumbrosacral Spine: Emphasizing Conservative Management; Readings in British Monetary Economics; and Delineating Toxic Areas by Canine Olfaction.

There's a report guaranteed not to be available from any online term paper mill. What instructor wouldn't be willing to pay money to grade a paper like that? Or to see the movie based on it?

When an undergraduate comes in saying that he or she can't think of a good term paper topic, we could give "POTLUCK" a spin and offer a real choice. When an undergraduate is making career decisions, he or she could RANDOMIZE and ask "Which of these ten books represents something I wouldn't mind spending the next four or five years learning about?"

But the real benefit would be in broadening the boxes in which we think. In times of change, we look at things that seem to be beyond our control and understanding. By imposing our own order on them, we create the new. We open the Bible and stab our finger at a verse, or toss yarrow stalks, or deal from the devil's deck, and the resulting pattern tells us what we already knew, but didn't want to admit.

A random word, a book seen by chance, can break us out of our mold. Little things can lead to far-reaching consequences. Somewhere a butterfly, dreaming that it is Chuang Chou, flutters its wings and starts a distant hurricane.

("Personnel officer to Robin . . ." cont. from page 729)

legitimate information as they can. This practice isn't widespread, but don't be surprised if it happens.

"Character references" don't exist. You're not a Victorian housemaid or footman who needs a "character" to prove moral rectitude. Your references are professional, period.

\section{Conclusion}

When composing a list of references, use common sense. Choose professional or workrelated contacts who best present your qualifications for a job. Ask your references for their permission before sending out application materials, and inform them about the job and the progress of your application. Many applicants neglect this aspect of jobhunting; paying attention to it can only help you.

\section{Note}

1. Mort Gerberg, Cartoon, The New Yorker, (July 1997). 


\section{Forthcoming Fall 2001}

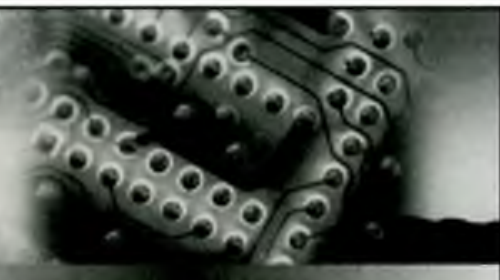

The Definitive Source Of Information In Physical Science Now Available In A New Edition

ENCYCLOPEDIA OF Physical Science and Technology, Third Edition

\section{Robert A. Meyers,} Editor-in-Chief

"An awesome work of scholarship... . a landmark of specialized publishing"

- CHICAG0 TRIBUNE (Review of First Edition)
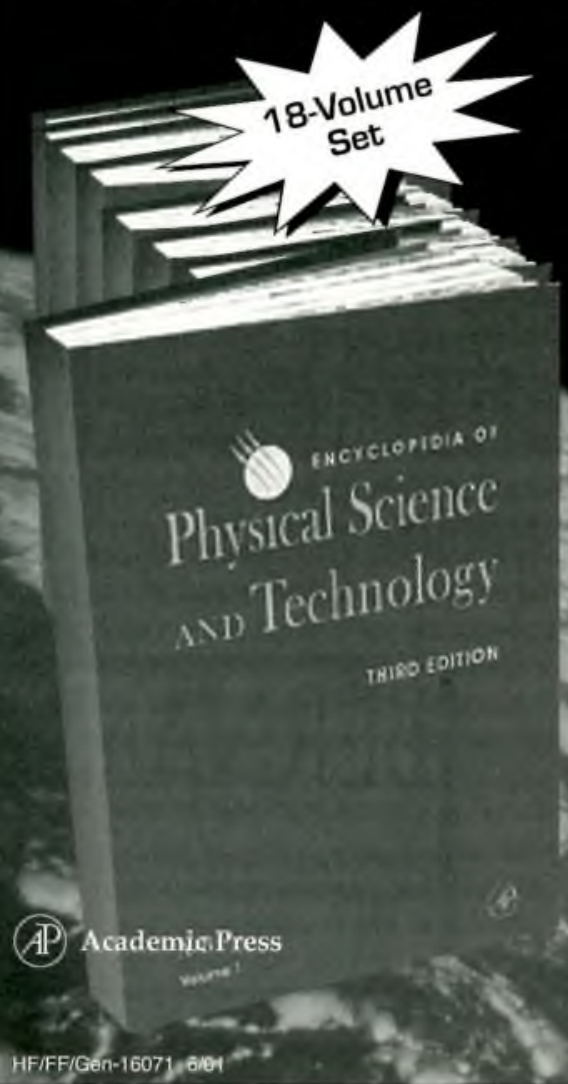

\section{Key Features}

- 18-Volume Set

- Editorial quality recognized by reviewers, librarians, and readers since 1987 in two previous editions

- From Academic Press, a highly acclaimed publisher of reference works such as Encyclopedia of Human Biology, Encyclopedia of Analytical Science, Encyclopedia of Biodiversity, Encyclopedia of Volcanoes, and Handbook of Nanostructured Materials and Nanotechnology

- Nearly 800 overview articles specifically commissioned for this work

- Approximately 14,000 pages of text supported by thousands of photos, illustrations, and tables

- Coverage of 17 general subject areas encompassing 125 specific fields of study

- Hundreds of new topics added for this edition, such as: Cell Death; Communication Satellite Systems; Digital Electronic Circuits; Earthquake Engineering; Fullerenes and Carbon Nanotubes; Greenhouse Effect; Humanoid Robots; Nanostructured Materials; Smart Pixels; Superstring Theory; WWW (World-Wide Web)

- New edition presents over $90 \%$ revised material, including $50 \%$ entirely new content

- Editorial Board composed of internationally renowned scientists including a number of Nobel Laureates

\section{Fall 2001,}

18-Volume Set

c. 14,800 pp., ISBN: 0-12-227410-5

*Pre-Publication:

$\$ 2,900.00$ (U. S. A.), $£ 1,935.00$ (U. K.)

List (tentative):

$\$ 3,750,00$ (U. S. A.), $\$ 2,335.00$ (U.K.)

* Prepublication price is valid three months after the month of publication

\section{Order From Your Favorite Vendior}




\section{Why order from Bernan?}

\section{We make it easier than ever for you to build and maintain your library of government information!}

\section{Bernan provides you with}

Publications issued by the U.S. government, independent U.S. government and quasi-official agencies.

Convenient print versions of selected U.S. government publications otherwise primarily made available in electronic form.

Expertly edited compilations of current, authoritative statistics. Some of these titles, such as Business Statistics of the United States, are continuations of popular titles no longer published by the U.S. government.

Important publications from a variety of intergovernmental agencies, including the United Nations, the World Trade Organization, the World Bank, the European Communities, the International Monetary Fund, and many others.

Be sure to request a copy of our new catalog!

Call us toll-free at (800) 865-3457, or visit us at www.bernan.com!
BERNAN ESSENTIAL GOVERNMENT INFORMATION

Call toll-free: (800) 865-3457 Fax toll-free: (800) 865-3450 Email: order@bernan.com Web site: www.bernan.com 